\title{
An Updated Assessment of the Technical Potential of Geothermal Heat Pump Applications in the United States
}

\section{Xiaobing Liu Arlene Anderson}

Patrick Hughes

Jeffrey Spitler

\begin{abstract}
This paper presents an updated assessment of the technical potential of applying geothermal heat pump (GHP) systems in businesses and bomes of the United States. The assessed technical potential includes energy savings, carbon emissions reductions, and consumer energy cost savings. This assessment is based on energy consumption data obtained from the latest survey of the energy consumption of residential and commercial buildings, conducted by the Department of Energy's Energy Information Administration. It uses energy savings data for GHP systems compared with existing conventional HV AC systems, which were obtained from the results of a series of computer simulations. The impacts of various climate and geological conditions, as well as the efficiency and market share of existing conventional HVAC systems, bave been taken into account in the assessment.
\end{abstract}

\section{INTRODUCTION}

Geothermal heat pumps (GHPs), also referred to as ground source heat pumps (GSHPs), have been proved capable of producing large reductions in energy use and $\mathrm{CO}_{2}$ emissions in buildings while satisfying the demands for space heating (SH), space cooling (SC), and domestic water heating (DWH).

The U.S. Department of Energy (DOE) Geothermal Technologies Office (GTO) is developing a Geothermal Vision Study (Vision Study) to articulate GTO's investment strategies; discuss geothermal growth scenarios for near future; and address all market segments of the geothermal industry. The GHP is one of the thermal applications of low-temperature geothermal resources included in the Vision Study. This paper provides a brief review of the current status of GHP applications in the United States and presents an updated assessment of the technical potential of GHP applications in both residential and commercial buildings.

\section{CURRENT STATUS}

GHPs have been used in all 50 states and the District of Columbia in the United States (EIA 2010). About 52\% of domestic GHP shipments went to ten states: Florida, Illinois, Indiana, Michigan, Minnesota, Missouri, New York, Ohio, Pennsylvania, and Texas. Current GHP applications are more concentrated in areas with a cold climate and high population density.

Xiaobing Liu (liux2@ornl.gov) is a R\&D staff and Patrick Hughes is a program manager at Oak Ridge National Laboratory. Jeffrey Spitler is a professor in mechanical engineering at Oklahoma State University. Arlene Anderson is a technology manager at the US DoE. 
A recent Navigant Research report (2013) indicates that the United States represented 29\% of global GHP installations by capacity, with 13,564 MWt (3.9 million tons, or 1.1 million GHP units given the typical GHP unit size is about $12 \mathrm{kWt}$ ) installed by 2012. These GHP systems provide space conditioning to roughly 199 million $\mathrm{m}^{2}$ (2.14 billion $\mathrm{ft}^{2}$ ) of residential and commercial buildings in the United States. The current market share of GHPs in the U.S. heating, ventilation, and air-conditioning (HVAC) market is approximately 1\% (EIA 2016a). A report issued by Priority Metrics Group (2009) estimated that the GHP market in the United States was about $\$ 3.7$ billion in 2009, including design, equipment, and installation. It is estimated that the total revenue from sales of domestic GHP units was approximately $\$ 319.5$ million in 2009 (EIA 2010).

The installed cost of GHPs varies widely, depending on geological conditions, building loads, system designs, and heat pump equipment. A few surveys have been conducted in the United States to collect cost information for GHPs. According to those surveys, the average cost of a commercial GHP system was $\$ 20.75 / \mathrm{ft}^{2}$ in 2012 (Kavanaugh et al. 2012). The typical price of a GHP system installed in a new home was in the range of $\$ 3,000-5,000$ per cooling ton (Ellis 2008).

The high initial cost and the lack of public awareness and strong governmental support are believed to be the major barriers preventing rapid adoption of GHPs in the United States. Recent low prices of oil and natural gas (NG) reduce the monetary value of the energy savings, which makes consumers less willing to invest in GHPs. Finally, tax credits for GHP installations will expire at the end of 2016 unless the industry is successful in its efforts to persuade Congress to extend the tax credits. The high initial cost barrier for GHP deployment may be overcome by breakthroughs in the following areas:

- Lower-cost ground heat exchangers and customized drilling techniques/equipment for GHP

- Better design of GHPs as a result of more information on the ground formation

- Volume manufacturing of GHP equipment

- Financial incentives or third party financing

- Integration of GHPs as a part of utility infrastructure in new developments

\section{METHODOLOGY}

The GHP technical potential is assessed based on (1) energy consumption data obtained from the latest survey of energy consumption in residential and commercial buildings, which is conducted by DOE's Energy Information Administration (EIA); and (2) energy savings data for GHPs compared with existing conventional HVAC systems, which are calculated based on computer simulation results. These computer simulations account for many factors affecting energy savings, including thermal loads (determined by the location, building envelope, and activity of the building), performance of the existing HVAC systems, local geological conditions (i.e., undisturbed ground temperature and ground thermal conductivity), and the performance of GHPs.

Unlike previous studies (Hughes 2008; Liu 2010), which relied on national or census region-level building energy consumption data, this study uses a database of county-level site energy consumption data in residential and commercial buildings, which was developed by the National Renewable Energy Laboratory (NREL) (McCabe et al. 2016). The county-level data for residential buildings were derived by disaggregating regional-level (states, aggregates of states) site energy consumption data for SH, SC, and DWH-reported in EIA's 2009 Residential Energy Consumption Survey (RECS; EIA 2013) - by the most recent count of housing units in each county, which is extracted from the National Historical Geographic Information System for a 5-year period (2009-2013). The countylevel data for commercial buildings were derived by multiplying the total square footage of each type of commercial building in each county - extracted from the Federal Energy Management Agency's (FEMA) Comprehensive Data Management System (CDMS) - by the average site energy intensities $\left(\mathrm{kBtu} / \mathrm{ft}^{2}\right)$ for $\mathrm{SH}, \mathrm{SC}$, and DWH for each particular type of commercial building in the climate zone in which the county is located. The average site energy 
intensities are provided in the 2009 Buildings Energy Data Book (DOE 2009) by principal building activity and climate zone.

The procedure for assessing the technical potential of GHPs is depicted in Figure 1 and explained in the following sections.

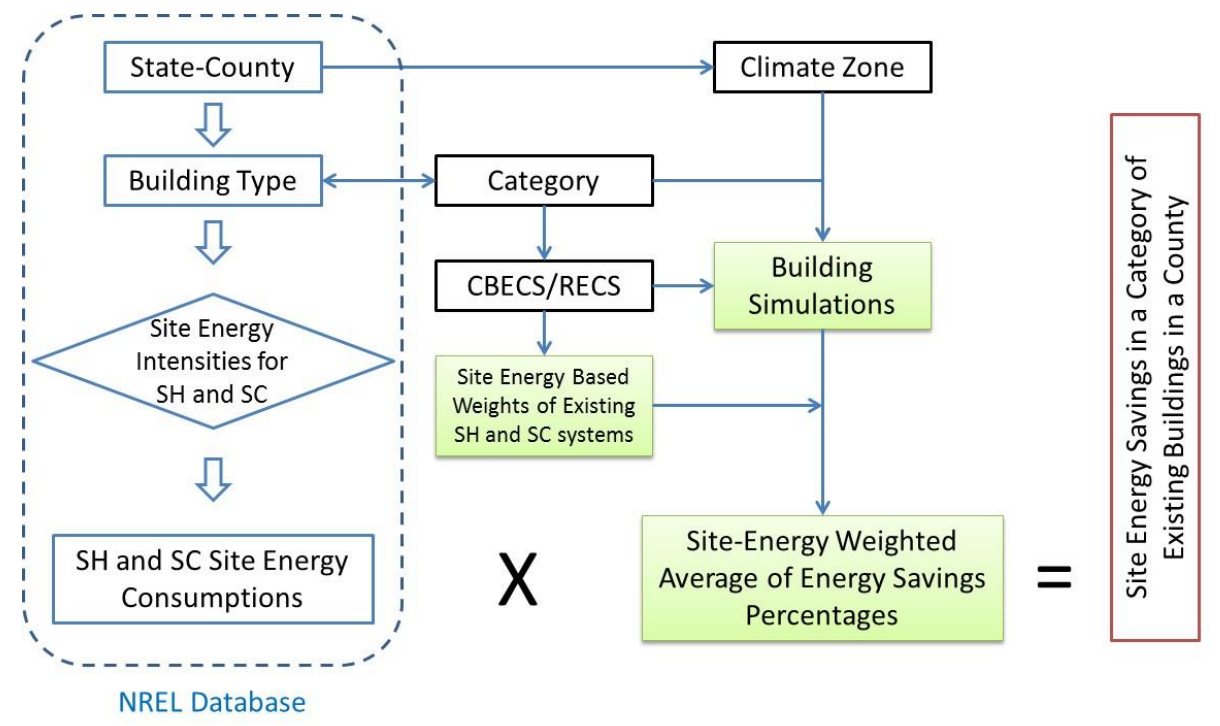

Figure 1 The process for evaluating the technical potential of energy savings by GHPs in a county.

\section{Reference buildings for residential and commercial sectors}

A reference building - a 1,644 $\mathrm{ft}^{2}\left(153 \mathrm{~m}^{2}\right)$ one-story, slab-on-grade, wood-frame house-is used to represent typical U.S. homes with SH (DOE 2009). There are 18 building types (adopted from FEMA's CDMS) in the countylevel commercial building energy consumption database. These building types are categorized into five groups based on the similarity of the building activities, and each group of commercial buildings is represented in this study by one of DOE's Commercial Reference Buildings (CRB; DOE 2012). Table 1 lists the categories of the building types and corresponding CRB models. Totally, 13 locations (cities) were selected to represent the major climate zones (IECC 2009) in the Continental United States. Simulations of the reference buildings were used to evaluate the relative differences in energy consumption between the existing conventional HVAC system and the GSHP system (i.e., the energy saving percentage) to satisfy the same SH and SC demands for a particular building in a given climate zone. It was found that the size of a particular type of building does not affect energy saving percentages significantly so the impact of building size on the energy saving percentage is not accounted for in this study. On the other hand, the characteristics of the existing conventional HVAC systems (e.g., efficiency of cooling equipment or energy source for $\mathrm{SH})$ make a significant difference in the energy saving percentage, which has been taken into account in this study as discussed below.

\section{Simulations of GHP system and baseline HVAC systems}

The residential GHP system simulated in this study consists of a packaged water-to-air heat pump (WAHP) unit with a two-stage scroll compressor and variable-speed electronically commutated fan-motor, a properly sized and highly energy-efficient loop fluid circulator, and a properly designed and installed vertical-borehole ground heat 
exchanger. The nominal cooling efficiency of the two-stage GHP unit is energy efficiency ratio (EER) ${ }^{1} 18.2$ at full capacity and EER 27 at $76 \%$ of full capacity. The nominal heating efficiency of the two-stage GHP unit is COP 4 at full capacity and COP 4.5 at $76 \%$ of full capacity ${ }^{2}$. The ground heat exchanger is sized to maintain the fluid temperature from the ground loop (the entering fluid temperature to the GHP unit) within the range of 30 to $95^{\circ} \mathrm{F}$ $\left(-1\right.$ to $\left.35^{\circ} \mathrm{C}\right)$ for given building loads, ground thermal properties, and undisturbed ground temperatures. The commercial GHP system simulated in this study is a distributed GHP system, which is the most commonly used GHP system in the United States (Liu et al. 2015). The simulated commercial GHP system consists of multiple two-stage WAHPs connected by a common water loop, with each WAHP serving an individual zone in the building. Although a GHP may also provide partial or full DWH (e.g., with a desuperheater or more advanced integrated heat pump), this study does not account for this service.

Table 1. Commercial Building Categories and Mapping

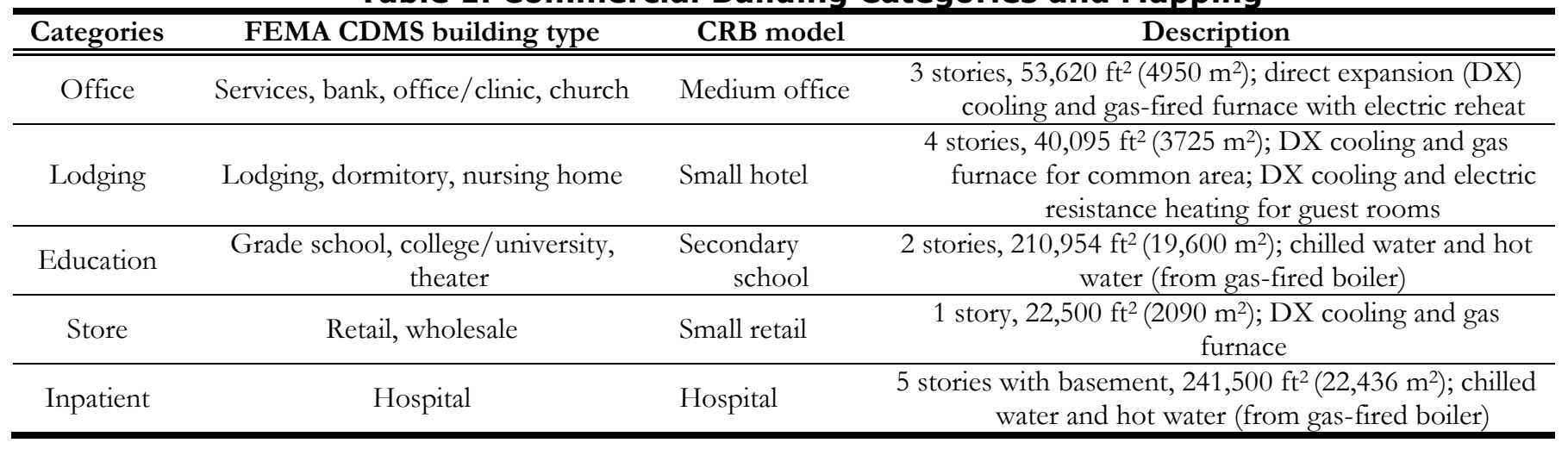

Each CRB model includes an HVAC system that is commonly used in the represented commercial building (Table 1). However, CBECS and RECS data indicate that there are many other existing HVAC systems serving each type of commercial buildings. The existing HVAC systems can be categorized based on the energy source for $\mathrm{SH}$ and SC. Table 2 lists different energy sources and their shares in the national site energy consumption for SH and SC of each group of buildings. These national-level contributions are determined based on the microdata of the most recent CBECS (EIA 2016b) and RECS (EIA 2013). As can be seen in Table 2, electricity is the exclusively predominant (with a more than $98 \%$ share) energy source for SC in both residential and commercial buildings. NG, heating oil, and propane are the predominant (with more than $80 \%$ combined share) energy sources for SH in commercial buildings. For single-family homes, the combined share of NG, heating oil, and propane is relatively lower (66.5\%), and electricity contributes $28.1 \%$ to the total site energy consumption for $\mathrm{SH}$, of which two-thirds is from heat pumps (mostly air-source heat pumps) and the rest from electric resistance heaters. Since electricity is used almost exclusively for SC, the main difference in terms of energy consumption among the various existing SC equipment types is their cooling efficiencies. The minimum code-compliant efficiencies specified in ASHRAE 90.1-2004 (ASHRAE 2004) were used in the representative CRB model to predict the exisiting SC equipment's energy consumptions.

On the other hand, energy consumption for SH depends on both the energy source and the efficiency of the existing SH equipment. Since the minimum code-compliant efficiencies of boilers or furnaces that use NG, oil, or propane are very similar (around 80\% Annual Fuel Utilization Efficiency according to ASHRAE 90.1-2004), the non-

\footnotetext{
${ }^{1}$ The EER is the cooling capacity (in British thermal units [Btu]/hour) of the unit divided by its electrical input (in watts) at standard conditions.

2 The COP and EER are measured at AHRI/ISO/ASHRAE/ANSI 13256-1 rating conditions: for cooling at full capacity, entering fluid temperature is $77^{\circ} \mathrm{F}$; for heating at full capacity, entering fluid temperature is $32^{\circ} \mathrm{F}$.
} 
electric heating equipment is modeled with the same heating efficiency. Therefore, two baseline $\mathrm{SH}$ systems were simulated for each representative commercial building-non-electric SH and electric resistance SH. Three baseline SH systems - non-electric, electric resistance, and air-source heat pump-were simulated for the representative residential building.

Table 2. Energy Sources of Existing HVAC Systems (from CBECS and RBES data)

\begin{tabular}{|c|c|c|c|c|}
\hline Reference building & Energy source for $\mathrm{SH}$ & Contribution & Energy source for SC & Contribution \\
\hline \multirow{2}{*}{ Office } & Electricity & $9.5 \%$ & Electricity & $99.4 \%$ \\
\hline & NG/oil/propane & $90.5 \%$ & Other & $0.6 \%$ \\
\hline \multirow{2}{*}{ Lodging } & Electricity & $17.8 \%$ & Electricity & $99.2 \%$ \\
\hline & NG/oil/propane & $82.6 \%$ & Other & $0.8 \%$ \\
\hline \multirow{2}{*}{ Education } & Electricity & $3.8 \%$ & Electricity & $98.6 \%$ \\
\hline & NG/oil/propane & $96.1 \%$ & Other & $1.4 \%$ \\
\hline \multirow{2}{*}{ Store } & Electricity & $9.5 \%$ & Electricity & $100 \%$ \\
\hline & NG/oil/propane & $90.1 \%$ & Other & $0.0 \%$ \\
\hline \multirow{2}{*}{ Inpatient } & Electricity & $0.5 \%$ & Electricity & $99.6 \%$ \\
\hline & NG/oil/propane & $99.4 \%$ & Other & $0.4 \%$ \\
\hline \multirow{3}{*}{ Single family home } & Electricity (resistance) & $9.4 \%$ & \multirow{3}{*}{ Electricity } & \multirow{3}{*}{$100 \%$} \\
\hline & NG/oil/propane & $66.5 \%$ & & \\
\hline & Electricity (air-source heat pump) & $18.7 \%$ & & \\
\hline
\end{tabular}

The energy consumptions of both the baseline HVAC systems and the GHPs applied in each of the representative buildings are predicted with eQUEST (Hirsch et al. 2016), a widely used building energy modeling program; it uses the most recent development of the DOE-2 program, which includes a module for simulating GHPs (Liu and Hellstrom 2006). The simulated baseline HVAC systems and the GHPs are sized to satisfy the SH and SC loads of each representative building and are operated with typical controls of these systems.

\section{Energy savings and other benefits in each county and nationwide}

Since the available county-level energy consumption data do not have information on the contribution of various existing HVAC systems in each county, the national shares of various $\mathrm{SH}$ systems (listed in Table 2) are used as weighting factors to account for different existing HVAC systems in each group of buildings. The average site energy saving percentage ( $A v g_{-} E S P c t_{-} S E$ ) resulting from retrofitting existing HVAC systems with GHPs for a given type of building in a particular county is calculated based on the site energy consumption of each existing HVAC system $\left(S y s_{-} S E\right)$ and the energy saving percentage ( $E S P c t_{-} S E$ ) of the simulated GHP system compared with each existing HVAC system, as expressed with Eq. (1).

$$
A v g_{-} E S P c t_{-} S E(j, k)=\frac{\sum_{i=1}^{l} S y s_{-} S E(i, j) \cdot E S P c t_{-} S E(i, j, k)}{\sum_{i=1}^{n} S y s_{-} S E(i, j)} .
$$

where $i, j$, and $k$ are the indexes of baseline HVAC system, building type, and county, respectively.

The maximum achievable county-level annual site energy savings ( $S E S$ ) from GHP retrofits for a given group of buildings in a county is calculated by multiplying the corresponding total site energy consumption of existing HVAC systems ( $S E$ ) with $A v g_{-} E S P c t_{-} S E$, as expressed with Eq. (2). 


$$
S E S(j, k)=S E(j, k) \times A v g_{-} E S P c t_{-} S E(j, k) .
$$

The national annual site energy savings (National_SES) resulting from retrofitting existing HVAC systems with GHPs in all buildings is calculated with Eq. (3).

$$
\text { National_SES }=\sum_{k=1}^{n} \sum_{j=1}^{m} S E S(j, k) .
$$

The savings in primary (source) energy, the reduction in $\mathrm{CO}_{2}$ emissions, and the savings in energy cost are calculated following the same procedure. In these calculations, the annual site energy consumption of each existing HVAC system is replaced with the associated primary energy consumption, $\mathrm{CO}_{2}$ emissions, or energy costs, which are converted from the site energy consumption data using corresponding conversion factors published by NREL (2007) and the 2014 state-level average electricity and natural gas prices (EIA 2016c, 2016d).

\section{RESULTS AND DISCUSSIONS}

Figure 2 shows the annual source energy saving percentages resulting from retrofitting the existing HVAC systems, which are included in the original CRB models, with GHPs at different locations (each representing a climate zone). As shown in Figure 2, the range and magnitude of source energy saving percentages vary widely by building type: $32-59 \%$ for a single-family home, $-4-50 \%$ for offices, $18-41 \%$ for lodgings, $17-33 \%$ for schools (education), and $-2-33 \%$ for stores. In general, more energy savings can be achieved at locations in cooler climates. These results indicate that the source energy saving percentages for residential buildings are higher than those for commercial buildings. The simulated residential building is conditioned continuously year-round (like most U.S. homes) and has less internal heat gain (e.g., from lighting and computers) than commercial buildings, which results in a higher ratio between SH and SC demands. It is thought to be the reason for the larger energy saving percentages of residential buildings. For buildings in hot climates (e.g., climate zones 2A and 2B), the energy savings in SH are very small; and the moderate energy savings in SC could be offset by the pumping energy of the GHPs.

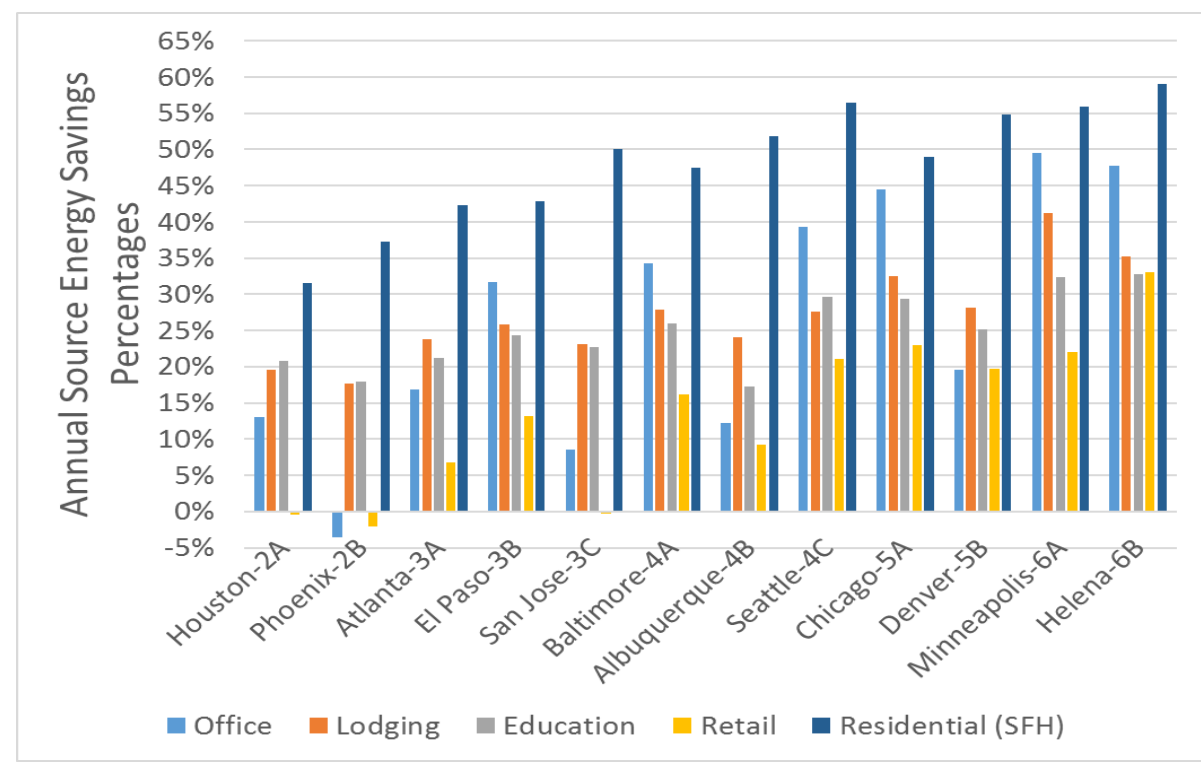

Figure 2 Annual source energy saving percentages by building principal activities and climate zones. 
Associated with source energy savings, GHP retofits also reduce carbon emissions. With more renewable power in the mix of electricity production in the future - a trend that has already begun - the emission factor of electricity will decrease, which in turn can further reduce the carbon emissions of GHPs.

The simulation results also indicate that GHPs can reduce annual peak electricity demand for all the investigated buildings except those in very hot climates (e.g., climate zone 2B), or in very cold climates (e.g., climate zone 6B) and with existing non-electric SH system. Although GHPs could result in more electricity consumption $(\mathrm{kWh})$ if they displace fossil fuels for $\mathrm{SH}$, they still reduce summer peak electricity demand because of their higher cooling efficiencies than that of the conventional SC systems.

Figure 3 shows the combined source energy savings potential in both residential and commercial buildings in each county of the United States (not including counties in Alaska and Hawaii). The amount of source energy savings in each county (in Trillion Btu) is color-coded as shown in the legend. As Figure 3 shows, there are substantial energy savings potentials $(>0.4$ Trillion Btu) in most counties in the United States, and the northeastern region has more counties with high source energy saving potential ( $>2$ Trillion Btu) than other regions.

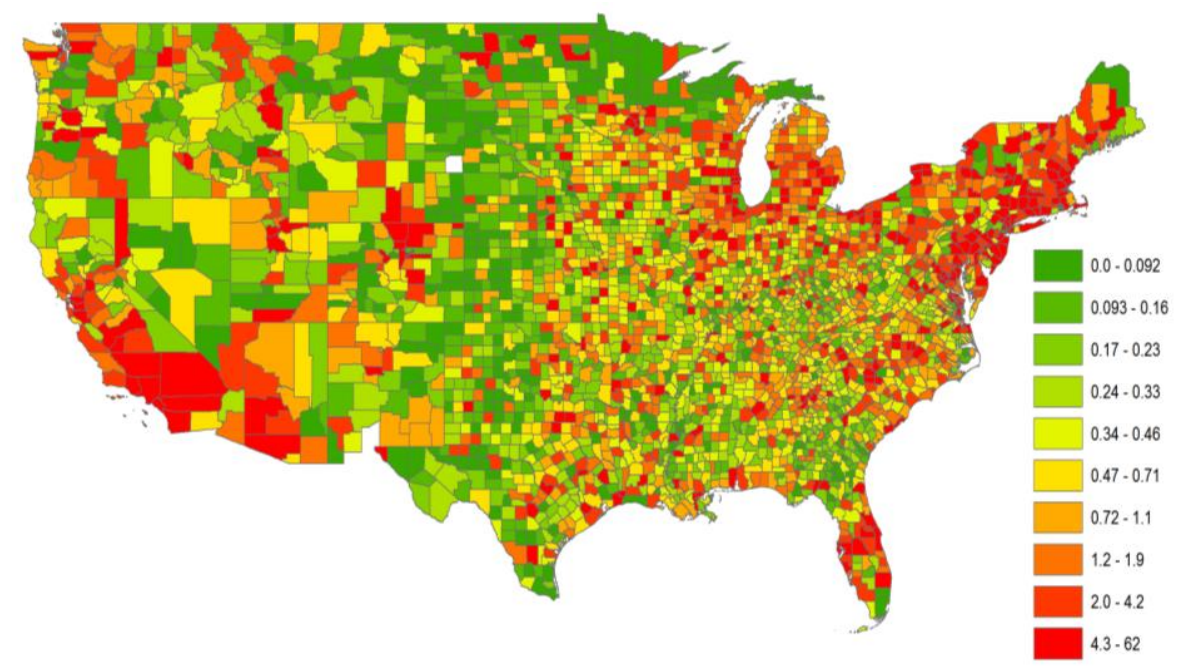

Figure 3 Source energy savings potential (Trillion Btu) in each county (not including Alaska and Hawaii) from retrofitting existing HVAC systems in residential and commercial buildings with GHPs

Table 3 lists the annual site energy savings, source energy savings, carbon emission reductions, and energy cost savings in the residential and commercial sectors, respectively, and the sum of the two sectors. As shown in the table, retrofitting the residential sector with GHPs has three times more potential than retrofitting the commercial sector. Combining both residential and commercial sectors, GHP retrofits have a potential to save 5.7 quadrillion Btu of primary energy, avoid 356.3 million metric tons $(\mathrm{Mt})$ of $\mathrm{CO}_{2}$ emissions, and reduce energy costs by $\$ 49.8$ billion, in each year.

The U.S. residential sector consumed 5.5 and 2.7 quads $\left(10^{15}\right.$ Btu or $\left.2.93 \cdot 10^{8} \mathrm{MWh}\right)$ of primary energy annually for SH and SC, respectively, in 2009 (EIA 2013). The 2009 building energy data book (DOE 2009) stated that 2.3 and 2.2 quads of primary energy are consumed annually for SH and SC in commercial buildings. The 5.7 quads of primary energy savings from GHP retrofits can reduce the national primary energy consumption for SH and SC by $45 \%$. If $20 \%$ of the technical potential can be realized, 1.1 quads of primary energy consumption will be avoided each year, which accounts for $9 \%$ of the current annual primary energy consumption in the entire building sector for SH and SC. 
Table 3. Technical Potential of GHP Retrofits in the United States

\begin{tabular}{ccccc}
\hline Categories & $\begin{array}{c}\text { Annual site energy } \\
\text { savings (quad Btu) }\end{array}$ & $\begin{array}{c}\text { Annual source energy } \\
\text { savings (quad Btu) }\end{array}$ & $\begin{array}{c}\text { Annual carbon emission } \\
\text { reductions (million Mt) }\end{array}$ & $\begin{array}{c}\text { Annual energy } \\
\text { cost savings } \\
\text { (billion \$) }\end{array}$ \\
\hline \hline Residential & 3.3 & 4.3 & 271.1 & 38.2 \\
\hline Commercial & 1.2 & 1.3 & 85.2 & 11.6 \\
\hline Total & 4.5 & 5.7 & 356.3 & 49.8 \\
\hline
\end{tabular}

\section{CONCLUSIONS AND FUTURE WORK}

This paper presents an analysis of the technical potential of GHP applications in both residential and commercial buildings in the United States. The analysis indicates that retrofitting existing conventional HVAC systems in U.S. residential and commercial buildings can result in significant energy savings and carbon emission reductions. The residential sector has three times more energy saving potential than the commercial sector. Combining both residential and commercial sectors, GHP retrofits have a potential to save 5.7 quadrillion Btu of primary energy, avoid 356.3 million metric tons $(\mathrm{Mt})$ of $\mathrm{CO}_{2}$ emissions, and reduce energy costs by $\$ 49.8$ billion, in each year. Given this huge energy savings potential, GHP could be a key component of national energy and climate change mitigation strategies.

High initial cost is the biggest barrier for GHP deployment, but it may be overcome by breakthroughs in the following areas:

- Lower-cost ground heat exchangers and customized drilling techniques/equipment for GHP

- Better design of GHPs as a result of more information on the ground formation

- Volume manufacturing of GHP equipment

- Financial incentives or third party financing

- Integration of GHPs as a part of utility infrastructure in new developments

\section{ACKNOWLEDGMENTS}

This work is funded by the Geothermal Technology Office of the U.S. Department of Energy.

\section{NOMENCLATURE}

$$
\begin{array}{ll}
E S P C t_{-} S E= & \text { regional average annual site energy saving percentage of the GHP system (\%) } \\
S y s_{-} S E= & \text { national annual site energy consumption of baseline system (kBtu) }
\end{array}
$$

\section{Subscripts}

$$
\begin{aligned}
i & =\text { index of baseline HVAC system } \\
j & =\text { index of building type } \\
k & =\text { index of county }
\end{aligned}
$$




\section{REFERENCES}

ASHRAE. (2004). ASHRAE Standard 90.1-2004 Energy Standard for Buildings except Low-Rise Residential Buildings. Atlanta, GA: American Society of Heating, Refrigerating and Air-Conditioning Engineers.

Department of Energy (DOE). (2009). 2009 Buildings Energy Data Book. Washington, DC: U.S. Department of Energy. http://buildingsdatabook.eren.doe.gov.

Department of Energy (DOE). (2012). DOE's Commercial Reference Buildings. Washington, DC: U.S. Department of Energy.

Energy Information Administration (EIA). (2010). Geothermal Heat Pump Manufacturing Activities 2009. U.S. Department of Energy-U.S. Energy Information Administration, Office of Electricity, Renewable, and Uranium Statistics, 2010. (Available at http://www.eia.gov/fuelrenewable.html).

Energy Information Administration (EIA). (2013). 2009 Residential Energy Consumption Survey (RECS) Preliminary Results. http://www.eia.gov/consumption/residential/data/2009/\#sqft

Energy Information Administration (EIA). (2016a). (Table: Residential Sector Equipment Stock and Efficiency) (http://www.eia.gov/beta/aeo/\#/?id=30-AEO2015\&region=0-

0\&cases $=$ ref2015 $\sim$ highmacro $\sim$ highprice $\sim$ aeo2014full\&start $=2012 \&$ end $=2040 \& \mathrm{f}=$ A\&chartindexed $=0$ )

Energy Information Administration (EIA). (2016b). 2012 Commercial Buildings Energy Consumption Survey (CBECS) Preliminary Results. http://www.eia.gov/consumption/commercial/reports/2012/preliminary/

Energy Information Administration (EIA). (2016c). Natural Gas Prices. (http://www.eia.gov/dnav/ng/ng_pri_sum_dcu_nus_m.htm)

Energy Information Administration (EIA). (2016d). Electricity Prices. (http://www.eia.gov/electricity/data.cfm\#sales)

Ellis, D. (2008). Field experience with ground-source heat pumps in affordable low energy housing. In Proceedings of 9th International Energy Agency Heat Pump Conference. Zurich, Switzerland, May 20-22.

Hirsch, J., et al. (2016). eQUEST program. Available at www.doe2.com

Hughes, P. (2008). Geothermal (Ground-Source) Heat Pumps: Market Status, Barriers to Adoption, and Actions to Overcome Barriers, ORNL/TM-2008/232. Oak Ridge, TN: Oak Ridge National Laboratory. http://www.ornl.gov/sci/ees/etsd/btric/pdfs/final\%20ornl\%20GHP\%20study\%201-16-09.pdf

International Energy Conservation Code (IECC) Climate Zone Map. 2009. https:/ energycode.pnl.gov/EnergyCodeReqs/

Kavanaugh, S., et al. (2012). Long-term commercial GSHP performance, Part 4: Installation costs. ASHRAE Journal 54(10).

Liu, X and G. Hellstrom. 2006. Enhancements of an Integrated Simulation Tool for Ground-Source Heat Pump System Design and Energy Analysis. Proceedings of the 10th International Conference on Thermal Energy Storage, Richard Stockton College of New Jersey, May 31-June 2, 2006.

Liu, X. (2010). Assessment of National Benefits from Retrofitting Existing Single-family Units with Ground Source Heat Pump Systems. ORNL/TM-2010/122. Oak Ridge, TN: Oak Ridge National Laboratory. http://www.ornl.gov/sci/ees/etsd/btric/publications/Xiaobing/Liu_GHP_8-30-2010.pdf

Liu, X., S. Lu, P. Hughes, and Z. Cai. (2015). A Comparative Study of the Status of GSHP Applications in the United States and China. Renewable and Sustainable Energy Reviews, Volume 48, August, pages 558-570.

McCabe, K., M. Gleason, T. Reber, and K. Young. (2016). Characterizing U.S. Heat Demand for Potential Application of Geothermal Direct Use. To be published at the 40 th GRC conference in October 2016.

National Renewable Energy Laboratory. (2007). Source Energy and Emission Factors for Energy Use in Buildings. Technical report NREL/TP-550-38617. Golden, CO: National Renewable Energy Laboratory.

Navigant Research. 2013. Geothermal heat pumps residential and commercial applications for geothermal heat pumps: Global Market Analysis and Forecasts. Navigant Consulting

Priority Metrics Group. 2009. Global geothermal heat pump market 2009: Energy beneath the Backyard. Business Wire. 